\title{
Evaluation of Helicobacter pylori in reflux oesophagitis and Barrett's oesophagus
}

\author{
M Newton, R Bryan, W R Burnham, M A Kamm
}

\begin{abstract}
Background-One of the major pathophysiological abnormalities in patients with gastro-oesophageal reflux disease is thought to involve transient lower oesophageal sphincter (LOS) relaxations. One component of the neural mechanism controlling the LOS appears to be a reflex arc whose afferent limb originates in the gastric fundus. As inflammation is known to be associated with neural activation an investigation was made to determine whether gastric infection with $H$ pylori is altered in prevalence or distribution in patients with reflux disease.

Methods-Five groups of subjects referred for endoscopy - group 1: 25 controls (asymptomatic individuals with anaemia and normal endoscopy); group 2: 36 subjects with erosive oesophagitis alone (Savary-Millar grades I-III); group 3: 16 subjects with duodenal ulcer alone; group 4: 15 subjects with oesophagitis with duodenal ulcer; group 5: 16 subjects with Barrett's oesophagus. No patients were receiving acid suppressants or antibiotics. An antral biopsy specimen was taken for a rapid urease test, and two biopsy specimens were taken from the antrum, fundus, and oesophagus (inflamed and non-inflamed) for histological evidence of inflammation and presence of $H$ pylori using a Giemsa stain.
\end{abstract}

Results-Nine $(36 \%)$ controls had $H$ pylori. Patients with duodenal ulcer alone had a significantly higher incidence of colonisation by $\boldsymbol{H}$ pylori than other groups (duodenal ulcer 15 (94\%); oesophagitis $13(36 \%)$; oesophagitis+duodenal ulcer $6(40 \%)$; Barrett's oesophagus $4(25 \%))$. $H$ pylori was not more common in oesophagitis. When $H$ pylori colonised the gastric antrum it was usually found in the gastric fundus. There was no difference in anatomical distribution of $H$ pylori in the different patient groups. In Barrett's oesophagus $H$ pylori was found in two of 16 in the metaplastic epithelium.

Conclusion-H pylori is not more common and its distribution does not differ in those with oesophagitis compared with control subjects, and is therefore unlikely to be aetiologically important in these patients. $H$ pylori, however, can colonise Barrett's epithelium.

(Gut 1997; 40: 9-13)
Keywords: gastro-oesophageal reflux, Helicobacter pylori, Barrett's oesophagus.

Both oesophageal and gastric factors have a significant role in the pathogenesis of gastrooesophageal reflux disease (GORD). The failure of normal lower oesophageal sphincter (LOS) function allows excessive oesophageal exposure to refluxed gastric contents. ${ }^{12}$ The main feature of this disturbed function is inappropriate transient LOS relaxation. ${ }^{3}{ }^{4}$ The cause of these non-swallow induced LOS relaxations is unknown. However, one component of the neural mechanism controlling the LOS seems to be a reflex arc whose afferent limb originates in the gastric fundus. ${ }^{56}$ Further evidence for a gastric abnormality includes diminished gastric adaptive relaxation associated with swallowing ${ }^{7}$ and disturbed gastric emptying ${ }^{8-10}$ in a proportion of patients with GORD.

Local factors in the stomach may affect the afferent mechanisms which partly control LOS behaviour. Infection with Helicobacter pylori is a major factor identified in causing gastroduodenal disease. Our first aim was therefore to determine if $H$ pylori might play a part in GORD, either by being present in a large proportion of patients or by being present in an abnormal distribution throughout the stomach and oesophagus of patients with GORD. Further rationale for such an investigation came from data suggesting that gastrooesophageal reflux occurs in a high proportion of patients with duodenal ulcer. ${ }^{1-15}$ Even when the LOS pressure was normal patients with duodenal ulcer may have a higher proportion of oesophageal acid reflux. ${ }^{11} \mathrm{~A}$ final aim of the study was to determine the relation between Barrett's oesophagus, a condition related to prolonged excessive gastro-oesophageal reflux, and the presence and anatomical distribution of Helicobacter infection.

\section{Methods}

PATIENTS (Table I)

Group 1: control subjects. Twenty five asymptomatic patients who were undergoing upper gastrointestinal endoscopy for the investigation of anaemia, but in whom endoscopy was normal.

Group 2: patients with reflux oesophagitis. Thirty six patients with symptoms suggestive of gastro-oesophageal reflux who were found to have grade I-III erosive oesophagitis (SavaryMiller modified classification $)^{16}$ were included. 
Group 3: patients with duodenal ulcer but no oesophagitis. Sixteen patients with duodenal ulcer but no symptoms or endoscopic findings suggestive of oesophagitis.

Group 4: patients with oesophagitis and duodenal ulcer. Fifteen patients with coexistent erosive oesophagitis (grade I-III) and duodenal ulcer disease.

Group 5: Barrett's oesophagus. Sixteen patients with Barrett's oesophagus.

In total, therefore, 108 patients undergoing elective diagnostic upper gastrointestinal endoscopy consented to additional biopsy specimens being taken during the procedure. Patients were excluded if they had taken antibiotics, bismuth compounds, $\mathrm{H}_{2}$ receptor antagonists, or proton pump inhibitors in the four weeks before endoscopy. All patients were asked about the use of non-steroidal antiinflammatory drugs (NSAIDs) in the preceding two weeks. The study was approved by the Barking, Havering, and Brentwood ethical committee, and patients gave informed consent.

\section{STUDY DESIGN}

During gastroscopy one antral biopsy specimen was taken for a rapid urease test. Two specimens were then taken from the gastric antrum and two from the gastric fundus for histological examination. In addition, in the asymptomatic controls (group 1) and patients with duodenal ulcer (group 3) two biopsy specimens were taken from the distal oesophagus $3 \mathrm{~cm}$ proximal to the squamocolumnar junction. In patients with oesophagitis, either without (group 2) or with duodenal ulcer (group 4), and patients with Barrett's oesophagus (group 5) two biopsy specimens were taken from the abnormal oesophageal mucosa (inflamed or columnar) and two specimens from the oesophageal mucosa $3 \mathrm{~cm}$ proximal to any oesophageal mucosal abnormality.

To prevent contamination of specimens taken from different sites biopsy specimens from each site were taken with a fresh pair of sterile forceps. The forceps were wiped with

TABLE I Demographic details of subject groups

\begin{tabular}{llllll}
\hline Group & No & Median age (range) & Men:women & Smokers & NSAIDst \\
\hline 1 Controls & 25 & $54(13-83)$ & $4: 21^{\star \star}$ & 0 & 1 \\
2 Oesophagitis & 36 & $52(11-78)$ & $22: 14$ & 6 & 4 \\
3 Duodenal ulcer & 16 & $47 \cdot 5(36-74)$ & $11: 5$ & 2 & 2 \\
4 Oesophagitis+duodenal ulcer & 15 & $66(32-87)$ & $13: 2$ & 0 & 2 \\
5 Barrett's oesophagus & 16 & $67 \cdot 5^{\star}(40-83)$ & $9: 7$ & 1 & 1 \\
\hline
\end{tabular}

${ }^{\star} \mathrm{p}=0.01$ compared with other groups; ${ }^{\star \star} \mathrm{p}=0.0005$ compared with other groups ( $\chi^{2}$ analysis) tNSAIDs=non-steroidal anti-inflammatory drugs.

TABLE II Number of positive antral rapid unease tests and number of $\mathrm{H}$ pylori positive biopsy specimens from each site in each group

\begin{tabular}{|c|c|c|c|c|c|c|}
\hline Group & No & $\begin{array}{l}\text { Rapid } \\
\text { urease } \\
\text { No (\%) }\end{array}$ & $\begin{array}{l}\text { Antrum } \\
\text { No (\%) }\end{array}$ & $\begin{array}{l}\text { Fundus } \\
\text { No (\%) }\end{array}$ & $\begin{array}{l}\text { Distal } \\
\text { oesophagus } \\
\text { No (\%) }\end{array}$ & $\begin{array}{l}\text { Proximal } \\
\text { oesophagus }\end{array}$ \\
\hline $\begin{array}{l}1 \text { Controls } \\
2 \text { Oesophagitis } \\
3 \text { Duodenal ulcer } \\
4 \text { Oesophagitis+duodenal ulcer } \\
5 \text { Barrett's oesophagitis }\end{array}$ & $\begin{array}{l}25 \\
36 \\
16 \\
15 \\
16\end{array}$ & $\begin{array}{l}9(36) \\
15(42) \\
15(94)^{\star} \\
6(40) \\
4(25)\end{array}$ & $\begin{array}{l}9(36) \\
13(36) \\
15(94)^{\star} \\
6(40) \\
4(25)\end{array}$ & $\begin{array}{l}9(36) \\
11(31) \\
11(69)^{\star} \\
5(33) \\
3(19)\end{array}$ & $\begin{array}{l}0 \\
0 \\
0 \\
0 \\
2(12 \cdot 5)\end{array}$ & $\begin{array}{l}0 \\
0 \\
0\end{array}$ \\
\hline
\end{tabular}

${ }^{\star} \mathrm{p}=0.008$ when compared with all other groups. alcohol on withdrawing them from the endoscope to remove any organisms which might have been present in the biopsy channel. Endoscopes were sterilised between procedures according to BSG guidelines. ${ }^{17}$

\section{Biopsy urease test}

An antral biopsy specimen was placed into a tube containing $0.5 \mathrm{ml}$ of freshly prepared $10 \%$ urea $(w / v)$ in deionised water to which had been added two drops of $1 \%$ phenol red as a pH indicator. $^{18}$ The test was read at one minute, one hour, and 24 hours and was regarded as positive if the indicator changed from yellow to red at any time.

\section{Histology}

To identify $H$ pylori, biopsy specimens were stained with haematoxylin and eosin and Giemsa stain. All specimens were assessed by two experienced pathologists unaware of the other's diagnosis. The number of $H$ pylori in each specimen was recorded as absent/few/ moderate/many. The pathologists were unaware of the rapid urease test result and the clinical diagnosis.

\section{STATISTICAL ANALYSIS}

Comparison of the degree of colonisation by $H$ pylori between different patient groups was made using the Kruskal-Wallis one way analysis of variance. The difference between the grade of $H$ pylori in the antrum and in the fundus in the same group of patients was analysed by Wilcoxon's sign rank test for paired data. A level of $p$ less than 0.05 was regarded as significant.

\section{Results}

Table I gives demographic details of the subject groups. The median age of patients with Barrett's oesophagus was significantly greater than that of other patient groups $(p=0.01$, Kruskal-Wallis one way analysis of variance) in keeping with the recognised older average age of patients with Barrett's oesophagus than of those with oesophagitis alone. ${ }^{19}$ The control group contained a higher proportion of women than the other groups ( $p=0.0005, \chi^{2}$ analysis), but there was no significant difference in the proportion of men between the other groups. Recent use of NSAIDs (including aspirin) was not significantly different between the groups.

Presence of $\mathrm{H}$ pylori (Table II)

There was an excellent agreement $(\chi=0.91)^{20}$ in identification of $H$ pylori between the two pathologists. Forty seven of the 49 patients with a positive rapid urease test had positive histological confirmation on antral biopsy. The two patients with a positive urease test but negative histological identification of $H$ pylori both had oesophagitis alone.

$H$ pylori was identified in a significantly higher number of patients with duodenal ulcer 
alone than with all the other groups $(H=13 \cdot 83$, $\mathrm{p}=0.008$ Kruskal-Wallis analysis of variance between groups. This was due to the increased prevalence of $H$ pylori in the group with duodenal ulcer). There was a significant difference in the proportion of patients colonised with $H$ pylori between those with duodenal ulcer alone compared with patients with coexistent duodenal ulcer and oesophagitis $\left(p<0.01, \chi^{2}\right.$ analysis).

An increased infection rate was not found in patients with oesophagitis when compared with asymptomatic controls.

\section{Distribution of $\mathrm{H}$ pylori in colonised patients (Figure)}

When $H$ pylori was identified histologically in the gastric fundus or in the oesophagus it was always found in the antral biopsy specimens also.

$H$ pylori was present in the gastric antrum and fundus in nine $(36 \%)$ of the control group (group 1). In six subjects the density of colonisation by $H$ pylori was the same in the antrum and fundus. In two subjects $H$ pylori was denser in the antrum than the fundus and in one, density was greater in the fundus. In no control subject was $H$ pylori found on oesophageal biopsy.

In patients with oesophagitis alone (group 2) $H$ pylori was detected in the gastric antrum on histology in 13 of 36 (36\%) cases. An antral urease test was positive in two additional patients without histological evidence of infection. Eleven of the 13 antral positive patients also had $H$ pylori in the gastric fundus. The number of $H$ pylori seen in the gastric fundus was either the same or less than in the antrum.

In patients with duodenal ulcer alone (group 3) $H$ pylori was detected in the antrum in 15 of $16(94 \%)$ cases. In 11 of these subjects where $H$ pylori was detected in the antrum it was also found in the gastric fundus, suggesting generalised colonisation of the stomach. Except in one patient the number of $H$ pylori seen in the fundus was always less than in the gastric antrum $(p=0 \cdot 04$, Wilcoxon's sign rank

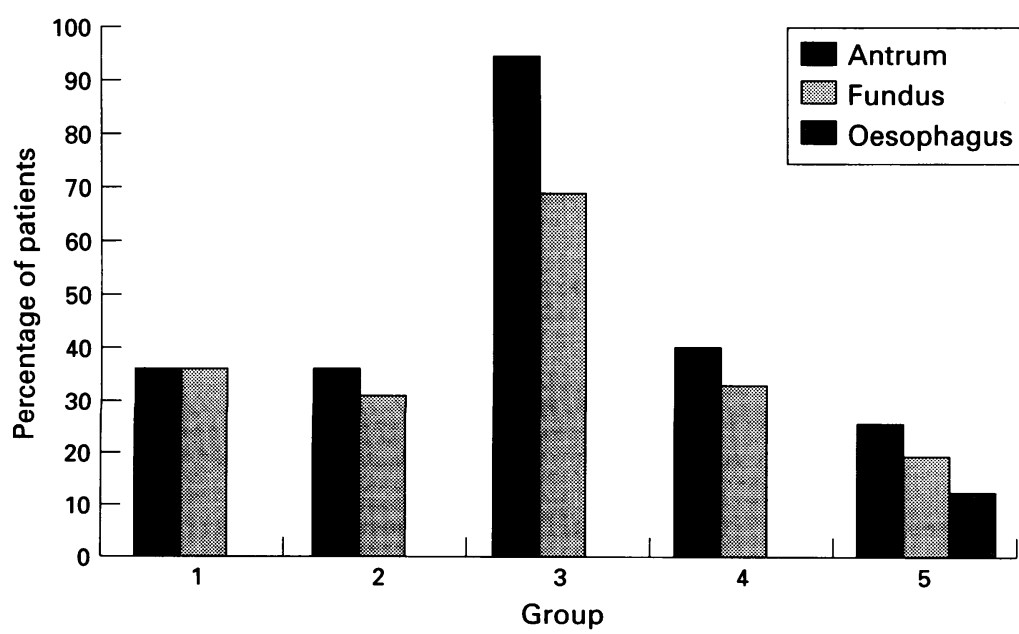

Distribution of $H$ pylori in gastric and oesophageal biopsy specimens. $x$ axis $=$ subject groups. $y$ axis=percentage of total patients in each group. Group $1=$ controls; group $2=$ subjects with oesophagitis; group $3=$ subjects with duodenal ulcer; group 4=subjects with oesophagitis+duodenal ulcer; group 5=subjects with Barrett's oesophagus. test). No patients had $H$ pylori on squamous oesophageal epithelium.

In patients with both oesophagitis and duodenal ulcer (group 4) $H$ pylori was detected in the antrum in only six of $15(40 \%)$ and in the fundus in five of $15(33 \%)$. There was no $H$ pylori detected in the oesophagus. In two of the $H$ pylori negative patients antral histology showed mild gastritis. Of these $H$ pylori negative patients, no patients smoked but two patients were taking NSAIDs (aspirin, ketoprofen) and three had taken ranitidine more than four weeks before endoscopy.

Four of $16(25 \%)$ patients with Barrett's oesophagus had $H$ pylori in the antrum and three of these also had positive fundal biopsy specimens. Two patients with Barrett's oesophagus had colonisation of the abnormal oesophageal mucosa. Of these patients, in one patient with a positive antral and fundal biopsy specimen $H$ pylori was also present in biopsy specimens taken from the abnormal oesophageal columnar epithelium but not in the more proximal squamous oesophageal specimens. In the other patient antral and oesophageal biopsy specimens from gastric metaplastic epithelium were positive but $H$ pylor was not detected in the fundus. In view of the patchy distribution of $H$ pylori in the gastric body $^{21}$ this may have been due to sampling. In two patients $H$ pylori was detected in the antrum alone.

\section{Discussion}

This study has shown no difference in the prevalence of $H$ pylori in patients with oesophagitis compared with controls. Previous studies have provided conflicting evidence about the association of $H$ pylori with gastrooesophageal reflux disease. Some have reported improvement in reflux after eradication of $H$ pylori. ${ }^{22}$ Francoual et $a^{23}$ suggested that in those with active oesophagitis $H$ pylori was found more commonly in the proximal stomach. Others have not found an association. ${ }^{24-29}$ However, these studies contained small numbers of subjects, limited defined patient groups, or limited data on the site of colonisation. The prevalence of $H$ pylori in our control group was similar to that seen in other studies of the prevalence of $H$ pylori in asymptomatic populations of a similar age. ${ }^{30-33}$ There was a higher proportion of women in the control group than in the other groups, reflecting the predominance of women in patients referred for the investigation of iron deficiency anaemia. The prevalence of $H$ pylori in the population is not different between men and women, ${ }^{30}{ }^{32}$ however, and is not affected by smoking. In our study when $H$ pylori was present it was usually found in both the gastric antrum and gastric fundus, suggesting that $H$ pylori colonises the whole stomach as has previously been shown, ${ }^{34}$ though others report a higher frequency of $H$ pylori in the gastric antrum than the fundus. ${ }^{36}$

In this study 140 of 322 biopsy specimens taken from oesophageal squamous epithelium were from patients with histological evidence 
of gastric $H$ pylori. Of these 140 specimens, none was positive for $H$ pylori. $H$ pylori is thought to colonise only gastric epithelium, and in the duodenum it is found in areas of gastric metaplasia. ${ }^{37} 38$ However, cultures of $H$ pylori were made from squamous oesophageal epithelium in patients with reflux oesophagitis, though histological identification failed. ${ }^{39} 40$ Such positive cultures might have been related to contamination. Alternatively, cultures may detect a smaller concentration of organisms than other methods. Other histological studies of $H$ pylori in reflux oesophagitis alone or in association with Barrett's oesophagus have failed to show colonisation of the squamous epithelium of the oesophagus..$^{23} 4142$

The finding of $H$ pylori in $94 \%$ of patients with duodenal ulcer alone is consistent with other reports. ${ }^{43}{ }^{44} \mathrm{We}$ found, however, that in those patients with both oesophagitis and duodenal ulcer together there was a reduced prevalence of $H$ pylori. Possibly, these patients represent a subpopulation of patients with duodenal ulcer disease. Two of the patients in this group were taking NSAIDs, but there were no other factors suggesting a cause of duodenal ulceration. Three patients had previously taken ranitidine, but this was stopped more than four weeks before endoscopy. Serology was not carried out on our patients to determine evidence of past infection with $H$ pylori. A previous study of $H$ pylori negative chronic duodenal ulceration showed idiopathic disease in $50 \%$ of patients. These patients were shown to have disturbed gastric function (hypergastrinaemia, increased acid secretion, and rapid gastric emptying). ${ }^{45}$ Some of these factors might contribute to oesophagitis in this group of patients. Oesophagitis has been reported in $39-72 \%$ of patients with chronic duodenal ulcer disease. ${ }^{11-15}$ The reason for this association is unclear, though increases in gastric acid secretion, hypergastrinaemia, and alterations in gastric emptying may all contribute to the pathophysiology of reflux oesophagitis. Colonisation with $H$ pylori has been shown to alter gastric function causing increased basal and post-prandial gastrin levels both in healthy subjects $^{46}$ and patients with duodenal ulcer. ${ }^{47}$ The low prevalence of $H$ pylori in our patients suggests that this factor did not contribute to the oesophagitis. The increased acid secretion seen in duodenal ulcer disease, however, seems to be independent of the presence of $\mathrm{H}_{\text {pylori, }}{ }^{48}$ and this may contribute to the development of oesophagitis in a subgroup of patients despite the fact that in the group of patients with oesophagitis as a whole there is little evidence for increased basal acid output. ${ }^{10}{ }^{49-51}$ Although eradication of $H$ pylori in patients with duodenal ulcer reduces gastric acid secretion, ${ }^{52} 53$ treatment of duodenal ulcer in patients with associated oesophagitis by eradication of $H$ pylori does not improve the oesophagitis. ${ }^{54} \mathrm{~A}$ proportion of patients with gastro-oesophageal reflux disease have evidence of delayed gastric emptying. ${ }^{8-10} 55$ Possibly, when the presence of a duodenal ulcer is associated with delayed gastric emptying there may be a predisposition to oesophagitis.
Of the four patients with Barrett's oesophagus who had gastric colonisation with $H$ pylori the organism was found in the oesophageal columnar mucosa in two. $H$ pylori has been shown to colonise the gastric epithelium of Barrett's oesophagus. ${ }^{41} 4256-58$ More recently Justin et al showed that in 30 patients with Barrett's oesophagus there was a higher colonisation rate in the metaplastic oesophageal mucosa when oesophagitis was also present. ${ }^{59}$ A larger study reported the presence of $H$ pylori in $30 \%$ of 94 patients with Barrett's oesophagus, but no association was found between $H$ pylori status and the presence of inflammation. ${ }^{60}$ In our study the number of patients with Barrett's oesophagus and $H$ pylori colonisation was too small to comment on this.

In summary, this study has not produced evidence to suggest that $H$ pylori plays a part in the pathogenesis of gastro-oesophageal reflux disease. Abnormalities of the gastric control of LOS function are likely to relate to other unidentified factors. Barrett's oesophagus is, however, associated with $H$ pylori colonisation of the abnormal mucosa in some patients.

1 DeMeester TR, Johnson LF, Joseph GJ. Patterns of gastrooesophageal reflux in health and disease. Ann Surg 1976; 184: 459-69.

2 Robertson D, Aldersley M, Shepherd H, Smith LC. Patterns of reflux in complicated oesophagitis. Gut 1987; 28: $1484-8$.

3 Dodds WJ, Dent J, Hogan WJ. Mechanisms of gastroesophageal reflux in patients with reflux esophagitis. $N$ Engl f Med 1982; 307: 1547-52.

4 Dent J, Holloway RH, Toouli J, Dodds WJ. Mechanisms of lower oesophageal sphincter incompetence in symptomatic patients with gastro-oesophageal reflux. Gut 1988; 29: $1020-8$.

5 Holloway RH, Hongo M, Berger K, McCallum RW. Gastric distension: a mechanism for post-prandial gastrodistension: a mechanism for post-prandial gas
esophageal reflux. Gastroenterology 1985; 89: 779-84.

6 Wyman JB, Dent J, Heddle R, Dodds WJ, Toouli J, Downton J. Control of belching by the lower oesophageal sphincter. Gut 1990; 31: 639-46.

7 Hartley MN, Walker SJ, Mackie CR. Abnormal gastric adaptive relaxation in patients with gastro-oesophageal reflux. Gut 1990; 31: 500-3

8 Maddern GJ, Chatterton BE, Collins PJ, Horowitz M, Shearman DJC, Jamieson GG. Solid and liquid gastric emptying in patients with gastro-oesophageal reflux. $B r \mathcal{F}$ Surg 1985; 72: 344-7.

9 McCallum RW, Berkowitz DM, Lerner E. Gastric emptying in patients with gastroesophageal reflux. Gastroenterology 1981;80: 285-91.

10 Baldi F, Corinaldesi R, Ferrarini F, Stanghellini V, Miglioli M, Barbara L. Gastric secretion and emptying of liquids in reflux oesophagitis. Dig Dis Sci 1981; 26: 886-9.

11 Flook D, Stoddard DJ. Gastro-oesophageal reflux and oesophagitis before and after vagotomy for duodenal ulcer. $\mathrm{Br}$ f Surg 1985; 72: 804-7.

12 Earlam RJ, Amerigo J, Kakavoulis T, Pollock DJ. Histological appearances of oesophagus, antrum and duodenum and their correlation with symptoms in a patient with a duodenal ulcer. Gut 1985; 26: 95-100.

13 De Moraes-Filho JPP, Zaterka S, Pinotti HW, Bettarello A. Esophagitis and duodenal ulcer. Digestion 1974; 11: 338-46.

14 Csendes A, Oster M, Moller JT, Flynn J, Funch-Jensen P, Overgaard $\mathrm{H}$, et al. Gastro-oesophageal reflux in Overgaard $\mathrm{H}$, et al. Gastro-oesophageal reflux in duodenal ulcer patients

15 Goldman MS, Rasch JR, Wiltsie DS, Finkel M. The incidence of esophagitis in peptic ulcer disease. Am f Dig Dis 1967; 12: 994-9.

16 Armstrong D, Monnier P, Nicolet M, Blum AL, Savary $M$. Endoscopic assessment of oesophagitis. Gullet 1991; 1: 63-7.

17 British Society of Gastroenterology. Cleaning and disinfection of equipment for gastrointestinal flexible endoscopy: interim recommendations of a working party of the British Society of Gastroenterology. Gut 1988; 29: $1134-51$.

8 Thillainayagam AV, Arvind AS, Cook RS, Harrison IG, Tabaqchali S, Farthing MJG. Diagnostic efficiency of an ultrarapid endoscopy room test for Helicobacter pylori. Gut 1991; 32: 467-9.

19 Iascone C, DeMeester TR, Little AG, Skinner DB. Barrett's oesophagus: functional assessment, proposed patho- 
genesis and surgical therapy. Arch Surg 1983; 118: 543-9.

20 Brennan P, Silman A. Statistical methods for assessin observer variability in clinical measures. BMF 1992; 304: 1491-4.

21 Wyatt JI, Primrose J, Dixon MF. Distribution of Campylobacter pylori in gastric biopsies. $\mathcal{F}$ Pathol 1988; 155: $350 \mathrm{~A}$.

22 Eles ZS, Winternitz T, Kupcsulik P, Forgacs A. Helicobacter pylori contamination in gastroesophageal reflux disease Gut 1995; 37: A222.

23 Francoual S, Lamy PH, Le Quintrec Y, Luboinski J, Petit J-C. Helicobacter pylori: has it a part in the lesion of reflux oesophagitis? F Infect Dis 1990; 162: 1414-15.

24 Johnston DA, Goudie B, Anderson JT, Hopwood D, Pennington CR. A possible role for Helicobacter pylori in the pathogenesis of reflux oesophagitis? World Congresses of Gastroenterology: Abstracts 1994: A1907.

25 Marshall BJ, Warren JR. Unidentified curved bacilli in the stomach of patients with gastritis and peptic ulceration. Lancet 1984 ; i: $1311-5$.

26 Deltenre M, De Koster E, Ferhat M, Deprez C. Helicobacter pylori, gastric histology and gastroesophageal cobacter pylori, gastric histology and
reflux disease. Endoscopy 1995; 27: S25.

27 Wittman T, Feher A, Rosztoczy A, Jarmay K, Lenart ZS Does the Helicobacter pylori $(\mathrm{Hp})$ infection aggravat gastroesophageal reflux disease? Gut 1995; 37: A224

28 Boixeda D, Gisbert JP, Canton R, Baleriola IA, Sanz E De Argila CM. Is there any association between Helicobacter pylori infection and reflux esophagitis? $G u t$ 1995; 37: A57.

29 De Koster E, Ferhat M, Deprez C, Deltenre M. Helicobacter pylori, gastric histology and gastroesophageal reflux disease. Gastroenterology 1995; 108: A81.

30 EUROGAST Study group. Epidemiology of, and risk factors for, Helicobacter pylori infection among 3194 factors for, Helicobacter pylori infection among 3194 asymptom

31 Perez-Perez GL, Dworkin BM, Chodos JE, Blaser MJ. Campylobacter pylori antibodies in humans. Ann Intern Med 1988; 109: 11-7.

32 Graham DY, Malaty HM, Evans DG, Evans DJ, Klein PD Adam E. Epidemiology of Helicobacter pylori in an asymptomatic population in the United States. Gastroenterology 1991; 100: 1495-501.

33 Dooley CP, Cohen H, Fitzgibbons PL, Bauer $M$, Appleman MD, Perez-Perez GI, et al. Prevalence of Helicobacter pylori infection and histological gastritis in asymptomatic persons. $N$ Engl $f$ Med 1989; 321: 1562-6.

34 Barthel JS, Bickel JT, Brophy M, Gitan RS, Madsen RW. The distribution of gastric mucosal pathology and gastric mucosal histopathology in symptomatic volunteers. Gastroenterology 1988; 94: A25.

35 Hazell S, Hennessey WB, Borody TJ, Carrick J, Ralston M Brady L, et al. Campylobacter pyloridis gastritis II: distribution of bacteria and associated inflammation in the gastroduodenal environment. Am $\mathcal{f}$ Gastroenterol 1987 82: $297-301$.

36 Bayerdorffer E, Lehn N, Hatz R, Mannes GA, Oertel H, Sauerbruch $\mathrm{T}$, et al. Difference in expression of Helicobacter pylori gastritis in antrum and body. Gastroenterology 1992; 102: 1575-82.

37 Johnston BJ, Reed PI, Ali MH. Campylobacter like organisms in duodenal and antral endoscopic biopsies:
relationship to inflammation. Gut 1986; 27: 1132-7.

38 Wyatt JI, Rathbone BJ, Dixon MF, Heatley RV. Campylobacter pyloridis and acid induced gastric metaplasia in the pathogenesis of duodenitis. $\mathcal{F}$ Clin Pathol 1987; 40 841-8.

39 Borkent MV, Beker JA. Treatment of ulcerative reflux oesophagitis with colloidal bismuth subcitrate in combination with cimetidine. Gut 1988; 29: 385-9.
40 Walker SJ, Birch PJ, Stewart M, Stoddard CJ, Hart CA Day DW. Patterns of colonisation of Campylobacter pylori in the oesophagus, stomach and duodenum. Gut 1989; 30: 1334-8.

41 Hazell SL, Carrick J, Lee A. Campylobacter pylori can infect the esophagus when gastric tissue is present. Gastroenterology 1988; 94: A178.

42 Paull G, Yardley JH. Gastric and esophageal Campylobacter pylori in patients with Barrett's esophagus. Gastroenterology 1988; 95: 216-8.

43 Marshall BJ, McGechie DB, Rogers PA, Glancy RJ. Pyloric Campylobacter infection and gastroduodenal disease Med $\mathcal{F}$ Aust 1985; 142: 439-44

44 Rice AE, Levi J, Dolby JM, Dunscombe PL, Smith A Clark J, et al. Campylobacter pyloridis in peptic ulcer disease: microbiology, pathology and scanning electron microscopy. Gut 1985; 26: 1183-8.

45 McColl KEL, El-Nujumi AM, Chittajallu RS, Dahill SW, Dorrian CA, El-Omar E, et al. A study of the pathogenesis of Helicobacter pylori negative chronic duodenal of Helicobacter pylori negat

46 Smith JTL, Pounder RE, Nwokolo CU, Lanzon-Miller S Evans DG, Graham DY, et al. Inappropriate hypergastrinaemia in asymptomatic healthy subjects infected with Helicobacter pylori. Gut 1990; 31: 522-5.

47 Levi S, Beardshall K, Haddad G, Playford R, Ghosh P, Calam J. Campylobacter and duodenal ulcers: the gastrin link. Lancet 1989; i: 1167-8.

48 Peterson WL, Barnett CC, Evans DJ Jr, Felman M Carmody T, Richardson $\mathrm{C}$, et al. Acid secretion and serum gastrin in normal subjects and patients with duodenal ulcer: the role of Helicobacter pylori. Am $\mathcal{f}$ Gastroenterol 1993; 88: 2038-43.

49 Boesby S. Relationship between gastro-oesophageal acid reflux, basal gastro-oesophageal sphincter pressure and gastric acid secretion. Scand f Gastroenterol 1977; 12: gastric

50 Williams CB, Lawrie JH, Forrest APM. Acid secretion in symptomatic sliding hiatus hernia. Lancet 1967; i: 184-5.

51 Stanciu C. Gastric secretion, gastroesophageal reflux and esophagitis. $A m \mathcal{F}$ Gastroenterol 1975; 64: 104-7.

52 Moss SF, Calam J. Acid secretion and sensitivity to gastrin in patients with duodenal ulcer: effect of eradication of Helicobacter pylori. Gut 1993; 34: 888-92.

53 McColl KEL, Fullarton GM, El-Nujumi AME MacDonald AM, Brown IL, Hilditch TE. Lowered gastric and gastric acidity after eradication of Campy-

54 Labenz J, Tillenberg B, Peitz U, Borsch G. Incidence of reflux esophagitis after cure of Helicobacter pylori infection in duodenal ulcer patients. Gastroenterology 1995; 108: A140.

55 Cunningham KM, Horowitz M, Riddell PS, Maddern GJ, Myers JC, Holloway RH, et al. Relations among auto nomic nerve dysfunction, oesophageal motility, and gastric emptying in gastro-oesophageal reflux disease. Gut 1991; 32: 1436-40.

56 Talley NJ, Cameron AJ, Shorter RG, Zinsmeister AR, Phillips SF. Campylobacter pylori and Barrett's esophagus. Mayo Clin Proc 1988; 63: 1176-80.

57 Talley R, Weinstein WM, Marin-Sorensen M, Schneidman D Reedy TJ, Van Deventer G. Campylobacter pylori colonisation of Barrett's esophagus. Gastroenterology 1988; 94: A454.

58 Ferreres J-C, Fernandez F, Vives AR, Gonzalez-Rodilla I Ursua I, Ramos R, et al. Helicobacter pylori in Barrett's esophagus. Histol Histopathol 1991; 6: 403-8.

59 Justin TA, Steele RJC. Helicobacter infection is associated with oesophagitis in patients with Barrett's oesophagus. Gut 1994; 35: A5.

60 Wright TA, Kingsnorth AN. High incidence of Helicobacte pylori colonisation of Barrett's oesophagus. Gut 1995; 36: A38. 